\title{
Philotheca papillata (Rutaceae), a new endangered species from north-eastern New South Wales
}

\author{
Ian R.H. Telford and Lachlan M. Copeland \\ Botany, Centre for Ecology, Evolution and Systematics, The University of New England, Armidale,
} NSW, 2351

\begin{abstract}
Philotheca papillata I.Telford \& L.M.Copel., apparently endemic to Sherwood Nature Reserve, north-eastern New South Wales, is described as new. Notes on its distribution, habitat and conservation status are provided. The species is illustrated, its distribution mapped and some of its attributes compared with related taxa.
\end{abstract}

\section{Introduction}

In 2000, while collecting material of Homoranthus floydii in Sherwood Nature Reserve near Glenreagh for a revision of that genus, one of us collected material of an associated species of Philotheca, then thought to be the widespread and variable $P$. salsolifolia. Recent revisionary studies in Philotheca sect. Philotheca (Wilson 1998) and the treatment of Philotheca for Flora of New South Wales (Weston \& Harden 2002), however, present no taxon with the unique combination of attributes of our material. The species which appear closest morphologically are P. reichenbachii Sieber ex Spreng., particularly similar vegetatively, and $P$. salsolifolia (Sm.) Druce.

\section{Methods}

Specimens of Philotheca reichenbachii and P. salsolifolia representing the known range of the taxa in New South Wales were borrowed from the National Herbarium of New South Wales (NSW) to augment the collections held in the N.C.W. Beadle Herbarium (NE). In this study, eight populations of $P$. reichenbachii and 21 of $P$. salsolifolia were scored. For morphological observations and measurements, dried herbarium material was reconstituted. Leaf characters (direction relative to axis of stem, length, shape in transvese section, presence of enlarged oil glands and indumentum) and floral characters (pedicel length, petal length, petal indumentum, petal colour, anther shape and indumentum of anther apicula) were recorded. 


\section{Discussion}

Philotheca reichenbachii is restricted to the Sydney region (Wilson 1998, Weston \& Harden 2002). Wilson (1998) recognised two subspecies of $P$. salsolifolia with their distributions recorded (Wilson 1998, Weston \& Harden 2002) as follows. P. salsolifolia subsp. salsolifolia is widespread in coastal and near-coastal New South Wales from near Taree south to near Bega, inland to Pilliga and West Wyalong. P. salsolifolia subsp. pedicellata Paul G.Wilson is restricted to the Angourie district of coastal north-eastern New South Wales.

The Philotheca population closest geographically to the locality of the new collection is of P. salsolifolia subsp.pedicellata at Sandon, c. $80 \mathrm{~km}$ to the north. This taxon differs from the Glenreagh plants in its triquetrous, non-verrucose, spreading leaves, long pedicellate flowers, glabrous keel of the petals and anther shape. P. salsolifolia subsp. salsolifolia has its closest population at North Haven, c. $180 \mathrm{~km}$ to the south. Specimens from here and other coastal populations differ in almost terete, non-verrucose leaves, petal indumentum and anther shape (Table 1). Inland populations of P. salsolifolia show considerable morphological differences and will not be discussed further here. This morphological variability and the disjunct distribution pattern of this species suggest a species complex in need of further investigation. Attributes scored for P. salsolifolia subsp. salsolifolia in Table 1 are for coastal 'type' populations from between Port Macquarie and Bega.

Comparison of the Glenreagh collections with $P$. reichenbachii show a remarkable similarity in vegetative attributes. In floral characters they differ in bearing smaller flowers with white to pale pink petals, the petal keel pubescent, anther shape and anther apicula lacking hair tufts (Table 1). It could be postulated that this new species and $P$. reichenbachii constitute a vicariant pair, but testing of relationships must await elucidation of end taxa. The Glenreagh material clearly represents a new species, described below.

Philotheca papillata I.Telford \& L.M.Copel. sp. nov.

P. reichenbachii similis sed petalis minoribus albidis vel subroseis atque pubescentibus in mediano abaxiali et antheris ad apicem glabris differt.

Type: New South Wales: North Coast: Sherwood Nature Reserve, I.R. Telford 12786, J.J. Bruhl \& L.M. Copeland, 14 Sep 2004 (holo: NSW; iso: BRI, CANB, HO, K, MEL, MO, NE, PERTH). (Specific locality details withheld for conservation purposes)

Shrub, erect, multistemmed, to $60 \mathrm{~cm}$ tall, bearing root suckers. Branchlets pilose, pale green beneath the white indumentum. Leaves incurved, narrow-elliptic, 9-12 $\mathrm{mm}$ long, $1-1.5 \mathrm{~mm}$ wide, acute, the margins recurved, crenate, verrucose with 4 or 5 glands on each side of lower surface, both surfaces papillate. Stipules minute, dark purple to black. Flowers solitary, terminal, on pedicels c. $0.5 \mathrm{~mm}$ long. Sepals 5, suborbicular, $1.5-2 \mathrm{~mm}$ long, pubescent. Corolla of 5 free petals, white to pale pink. Petals elliptic, 7-10 mm long, pubescent on both surfaces, the abaxial surface sparsely verrucose. Stamens 10 , 6.5-8 mm long. Filaments fused at base for $4-5 \mathrm{~mm}$. Anthers ovate, apiculate, c. $1.2 \mathrm{~mm}$ long, the apicula glabrous or minutely papillate. Gynoecium of 5 basally-fused carpels, the carpels tomentose, pale green; style terete, broadening towards the base, c. $4 \mathrm{~mm}$ long, pilose on lower three-quarters; stigma capitate, minutely 5-lobed. Disc obscure. Fruit not seen. (Fig. 1). 

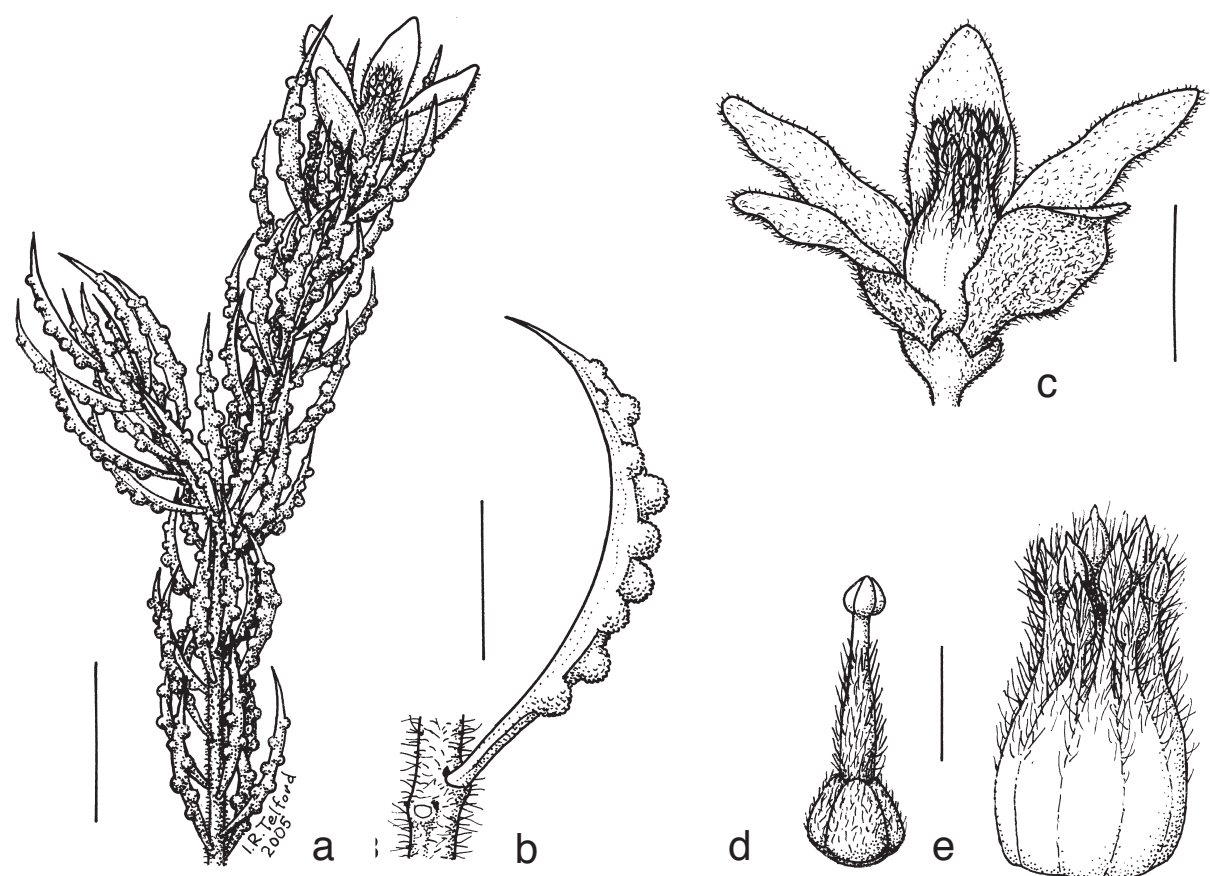

Fig. 1. Philotheca papillata a, flowering branch; b, leaf; c, flower; d, androecium; e, gynoecium. Scale bar: $\mathrm{a}=10 \mathrm{~mm} ; \mathrm{b}, \mathrm{c}=5 \mathrm{~mm} ; \mathrm{d}, \mathrm{e}=2 \mathrm{~mm}$. (all from L.M. Copeland $2605 \&$ P.R. Sherringham).

Additional specimens examined: New South Wales: North Coast: Sherwood Nature Reserve, L.M. Copeland 2605 \& P.R. Sherringham, 2 Sep 2000 (NE); L.M. Copeland 3758, 4 Jul 2004 (CANB, NE, NSW); I.R. Telford 12787, J.J.Bruhl \& L.M.Copeland, 14 Sep 2004 (NE). (Specific locality details of all specimens withheld for conservation purposes).

Distribution: Philotheca papillata is known only from the type locality in Sherwood Nature Reserve, east of Glenreagh (Fig. 2). In spite of widespread searches in areas of similar geology and geomorphology (sandstone cliff lines and rocky slopes of the Grafton Formation and Kangaroo Creek Sandstone) between Chambigne Nature Reserve, Whitemans Creek, Coaldale and Flaggy Creek Nature Reserve, no further populations were discovered. The dissected sandstone country between Glenreagh and Woolgoolga provides habitat for several other narrowly endemic species including Homoranthus floydii, Boronia umbellata, B. hapalophylla and an undescribed species of Lasiopetalum.

Flowering: flowers have only been observed in September although the species is likely to flower from mid August through to at least early October.

Habitat: this species occurs in a heath community with Banksia oblongifolia, Leptospermum trinervium, Phebalium woombye, Bossiaea rhombifolia, Xanthorrhoea johnsonii and Philothrix deusta with occasional emergent malleed Eucalyptus planchoniana. The substrate is a shallow sandy soil over sandstone (Grafton Formation) along escarpment cliff tops at an altitude of c. $350 \mathrm{~m}$. The site appears to have a high fire frequency and the root-suckering habit of the species probably assists in maintaining the population. 
Table 1. Comparison of some distinguishing attributes between Philotheca papillata, $P$. reichenbachii and $P$. salsolifolia s.s.

$\begin{array}{llll}\text { Character } & \text { P. papillata } & \text { P. reichenbachii } & \text { P. salsolifolia s.s. } \\ \text { Leaf lamina } & \text { incurved } & \pm \text { incurved } & \pm \text { straight } \\ \text { Leaf surface } & \text { papillate } & \text { hispid, papillate } & \text { glabrous-sparsely ciliate } \\ \text { Leaf margin } & \text { verrucose } & \text { verrucose } & \text { smooth } \\ \text { Petal length } & 7-8 \mathrm{~mm} & 8-13 \mathrm{~mm} & 6-10 \mathrm{~mm} \\ \text { Corolla outer surface } & \text { keel tomentose } & \text { keel } \pm \text { glabrous } & \text { keel glabrous } \\ \text { Corolla colour } & \text { white-pale pink } & \text { purple } & \text { pink-purple } \\ \text { Anther apex } & \text { glabrous } & \text { with hair tuft } & \text { glabrous } \\ \text { Anther shape } & \text { ovoidal } & \text { cylindroidal } & \text { narrow-ellipsoidal }\end{array}$

Conservation status: Philotheca papillata is apparently restricted to Sherwood Nature Reserve where a single population is known of c. 150 individuals along c. $200 \mathrm{~m}$ of escarpment edge. An inappropriate fire regime could present a major threat but resprouting by root suckers could potentially allow survival. The population is also close to an informal lookout and a series of obscure walking tracks. Although all known plants occur within the reserve, the species should still be considered endangered due to its highly restricted distribution and small population size. Following the criteria of Briggs and Leigh (1996) a conservation code of 2ECit is recommended.

Etymology: the epithet papillata is from the Latin (papillatus=bearing papillae), in reference to the distinctive leaf surfaces.

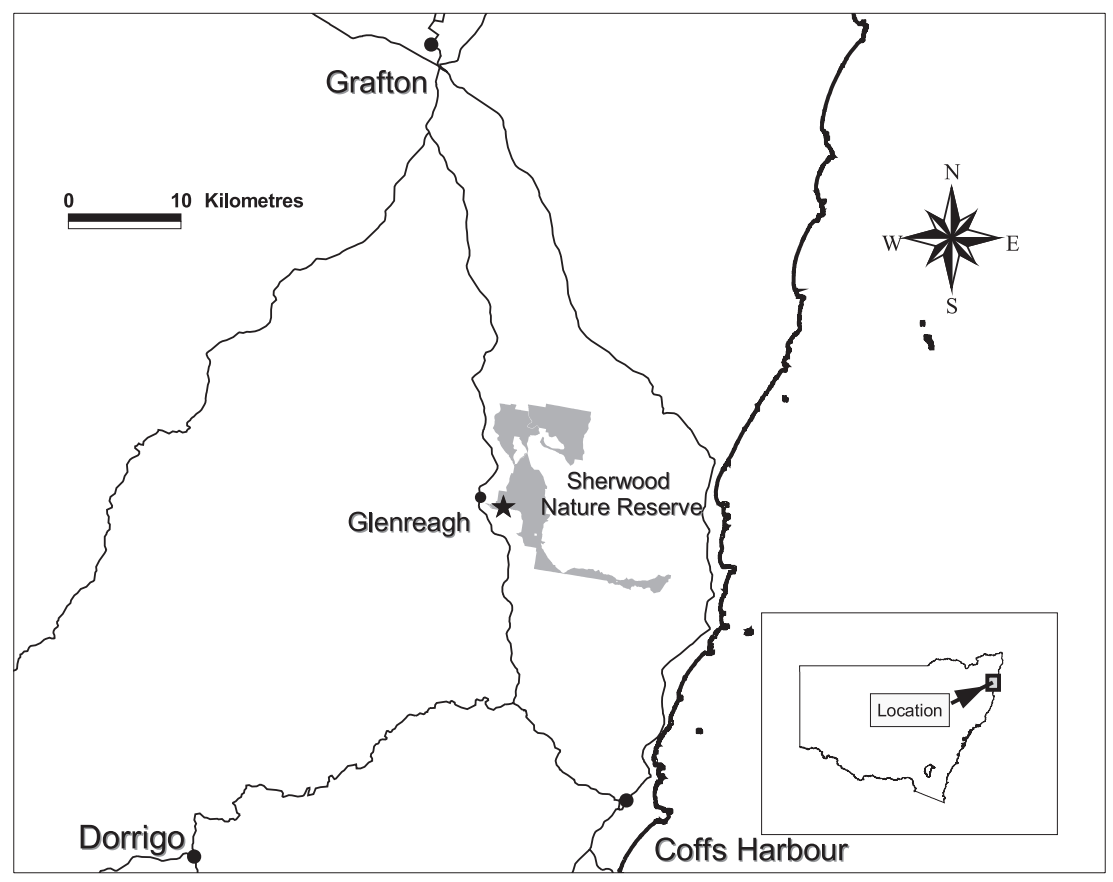

Fig. 2. Approximate location of Philotheca papillata (denoted by $\star$ ) in Sherwood Nature Reserve, north-eastern New South Wales. 


\section{Acknowledgments}

We would like to thank Jeremy Bruhl for assistance in the field and constructive comments on the manuscript. Paul Sherringham of the NSW National Parks and Wildlife Service is also thanked for field assistance and jointly discovering the new species. Peter Wilson kindly provided the Latin diagnosis.

\section{References}

Briggs JD \& Leigh JH (1996) Rare or Threatened Australian Plants, revised edition. (CSIRO Publishing: Collingwood)

Weston PH \& Harden GJ (2002) Philotheca. Pp. 292-299 in Harden GJ (ed.) Flora of New South Wales, vol. 2, 2nd edition. (New South Wales University Press: Kensington)

Wilson PG (1998) A taxonomic review of the genera Eriostemon and Philotheca (Rutaceae: Boronieae). Nuytsia 12: 239-265.

Manuscript received 31 May 2005, accepted 24 November 2005 



\title{
Pimelea cremnophila (Thymelaeaceae), a new species from the New England Tablelands escarpment of northern New South Wales
}

\author{
Lachlan M. Copeland and Ian R.H. Telford
}

Botany, Centre for Ecology, Evolution and Systematics, The University of New England, Armidale, NSW 2351

\begin{abstract}
Pimelea cremnophila L.M.Copel. \& I.Telford, a rare new species endemic to the Macleay Gorges east of Walcha, is described. Notes are given on its distribution, habitat and conservation status. Although all plants are known from a conservation reserve the species is considered to be endangered due to its restricted distribution and small population size.
\end{abstract}

\section{Introduction}

The gorge country of the eastern escarpment of the New England Tableland is well known as a 'hot spot' for endemism. Narrowly endemic taxa in the Macleay and Guy Fawkes River gorges include Hakea fraseri, Phebalium squamulosum subsp. verrucosum, Leucopogon trichostylus, Zieria floydii and Bertya ingramii. Other taxa thought to be endemic to the area include undescribed members of Westringia, Persoonia, Acalypha, Zieria, Callistemon, Eucalyptus, Leionema and Olearia (Briggs \& Leigh 1996; Copeland 1997). Recent fieldwork in Oxley Wild Rivers National Park has yielded a species of Pimelea which did not fit any currently known taxa in the treatments of Threlfall (1983), Rye (1990) and Harden (1990). An examination of Pimelea specimens held in CANB, NSW and NE also supported the recognition of the Macleay Gorges Pimelea as distinct (herbarium abbreviations follow Holmgren et al. 1990). This paper describes the new species and gives notes on its distribution, habitat and conservation status.

Pimelea cremnophila L.M.Copel. \& I.Telford sp. nov.

P. umbratica similis sed indumento foliari caulinoque longiore densioreque et filamentis staminum distinctis differt.

Type: New South Wales: Northern Tablelands: Oxley Wild Rivers National Park, c. $40 \mathrm{~km}$ ENE of Walcha, $30^{\circ} 55^{\prime} \mathrm{S}, 151^{\circ} 52^{\prime} \mathrm{E}$, L.M. Copeland 3816, I.R. Telford \& P.J. Lupica, 13 Oct 2004 (holo NSW; iso BRI, CANB, CHR, HO, K, MEL, MO, NE). (Specific locality details withheld for conservation purposes).

Erect shrub to $2.5 \mathrm{~m}$ tall. Stems red-brown, hirsute with strigose white antrorse hairs to 3 $\mathrm{mm}$ long, glabrescent with age. Leaves opposite, petiolate; petioles c. $1 \mathrm{~mm}$ long, densely 
hairy; lamina narrow-elliptic to narrow-ovate, acute, 10-37 mm long, 2.5-6 mm wide, secondary venation indistinct, the adaxial surface glabrous or sparsely hairy mainly along the midvein, the abaxial surface paler and hirsute with scattered white, strigose hairs, the hairs denser and longer, to $2.5 \mathrm{~mm}$ long, on the margins. Inflorescences axillary or terminal, extending up to 15 nodes below shoot apex,1-4 flowered, condensed racemes 2-3 mm long; peduncle c. $1 \mathrm{~mm}$ long, strigose; bracts leaf-like, c. 2.5-5 mm long, caducous. Flowers functionally male, bisexual or functionally female; subsessile. Hypanthium antrorse hairy outside, glabrous inside, greenish-white; sepals 4, narrowovate. Male flowers with hypanthium 6-8 mm long; sepals 3-4 $\mathrm{mm}$ long; stamens 2, rarely 3 , inserted near summit of hypanthium; filaments c. $1 \mathrm{~mm}$ long; anthers narrowoblong, c. $1.7 \mathrm{~mm}$ long; pistillode c. $1 \mathrm{~mm}$ long. Bisexual flowers protandrous, with hypanthium 4-6.5 mm long; sepals 3-4 mm long; stamens similar to male flowers; ovary c. $1.5 \mathrm{~mm}$ long, with erect hairs at apex; style eventually exserted; stigma brushlike. Female flowers with hypanthium 3-4.5 mm long, circumscissile c. $1 \mathrm{~mm}$ below sepal attachment; sepals 1.5-2.5 mm long; staminodes minute; gynoecium similar to bisexual flowers. Fruit dry, ovoid, enclosed in the persistent base of the hypanthium, pale green. Seed ovoid, 3-3.5 mm long, c. $2 \mathrm{~mm}$ wide, with minute longitudinal, foveate furrows, red-brown (Fig.1).

Additional specimens examined: New South Wales: Northern Tablelands: Oxley Wild Rivers National Park: c. $40 \mathrm{~km}$ ENE of Walcha, 30 $55^{\prime} \mathrm{S}, 151^{\circ} 52^{\prime} \mathrm{E}$, L.M. Copeland 3444 \& P. Lupica, 24 Oct 2002, (BRI, CANB, MEL, NSW, NE); c. $40 \mathrm{~km}$ ENE of Walcha, 30 $55^{\prime} \mathrm{S}, 151^{\circ} 52^{\prime} \mathrm{E}$, L.M. Copeland 3608 \& S. Doak, 8 Oct 2003, (CANB, MEL, NE, NSW); rim of gorge of Spring Ck., c. $38 \mathrm{~km}$ E of Walcha, $30^{\circ} 55^{\prime} \mathrm{S}, 151^{\circ} 51^{\prime} \mathrm{E}$, L.M. Copeland 3735, J.J. Bruhl \& I.R. Telford, 4 May 2004, (BRI, CANB, NSW, NE); c. 38 km ENE of Walcha, 3055'S, 151 ${ }^{\circ} 51^{\prime}$ E, L.M. Copeland 3819, I.R. Telford \& P.J. Lupica, 13 Oct 2004, (AD, NSW, NE); c. $37 \mathrm{~km}$ ENE of Walcha, edge of gorge of Redmans Ck, 30 56'S, 151 ${ }^{\circ} 51^{\prime} \mathrm{E}$, L.M. Copeland 3822, I.R. Telford \& P.J. Lupica, 13 Oct 2004, (AD, AK, BRI, CANB, CHR, HO, MEL, NSW, NE). (Specific locality details of all specimens withheld for conservation purposes).

Distribution: apparently confined to gorge rims in the southern part of Oxley Wild Rivers National Park, approximately $40 \mathrm{~km}$ E of Walcha. Several small populations are scattered along a $5 \mathrm{~km}$ stretch of gorge rim. A large area of similar habitat exists within the park and further searches of this area of gorge rim could potentially yield additional populations.

Habitat: all plants observed grow in a shallow, skeletal loam over metasediments on exposed cliff tops or more sheltered cliff-side sites with south-westerly to southeasterly aspects. Altitude ranges from 1050-1090 m. Associated species include Allocasuarina littoralis, Eucalyptus retinens, E. campanulata, Acacia blakei subsp. diphylla, Maytenus silvestris, Prostanthera rhombea, Dodonaea rhombifolia, Astrotricha longifolia, Ozothamnus obcordatus, Persoonia media, Callistemon sp. nov., Correa reflexa var. reflexa, Lepidosperma elatius s.l., L. laterale, Rhodanthe sp. nov. and Notodanthonia longifolia.

Flowering: flowers have only been observed in early to mid October, but the presence of unopened floral buds and young fruits on specimens suggests that the species is likely to flower throughout spring.

Conservation status: the species is currently known from fewer than 100 individuals and relatively few juveniles have been observed. Potential threats include an inappropriate fire regime and grazing by feral goats. Several mature individuals appeared to die during 

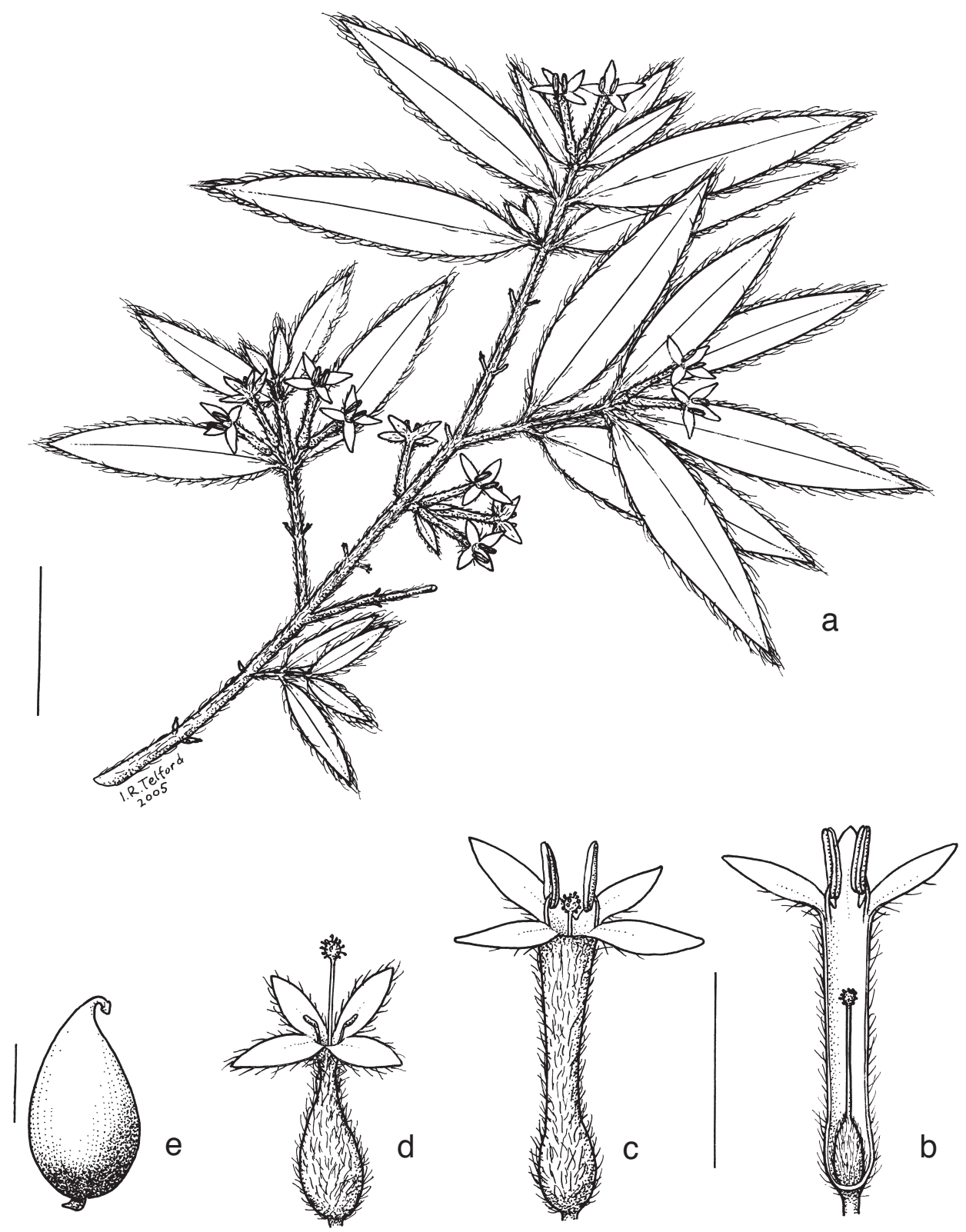

Fig. 1. Pimelea cremnophila $\mathbf{a}$, flowering branch; $\mathbf{b}$, bisexual flower prior to elongation of style, with part of hypanthium and one sepal removed; c, bisexual flower; d, functionally female flower; e, seed. Scale bar: $\mathrm{a}=10 \mathrm{~mm}$; $\mathrm{b}-\mathrm{d}=5 \mathrm{~mm}$; e $=1 \mathrm{~mm}$. (a, b, e, from L.M. Copeland 3608 \& S. Doak; c, d, from L.M. Copeland 3816, I.R. Telford \& P. Lupica) 


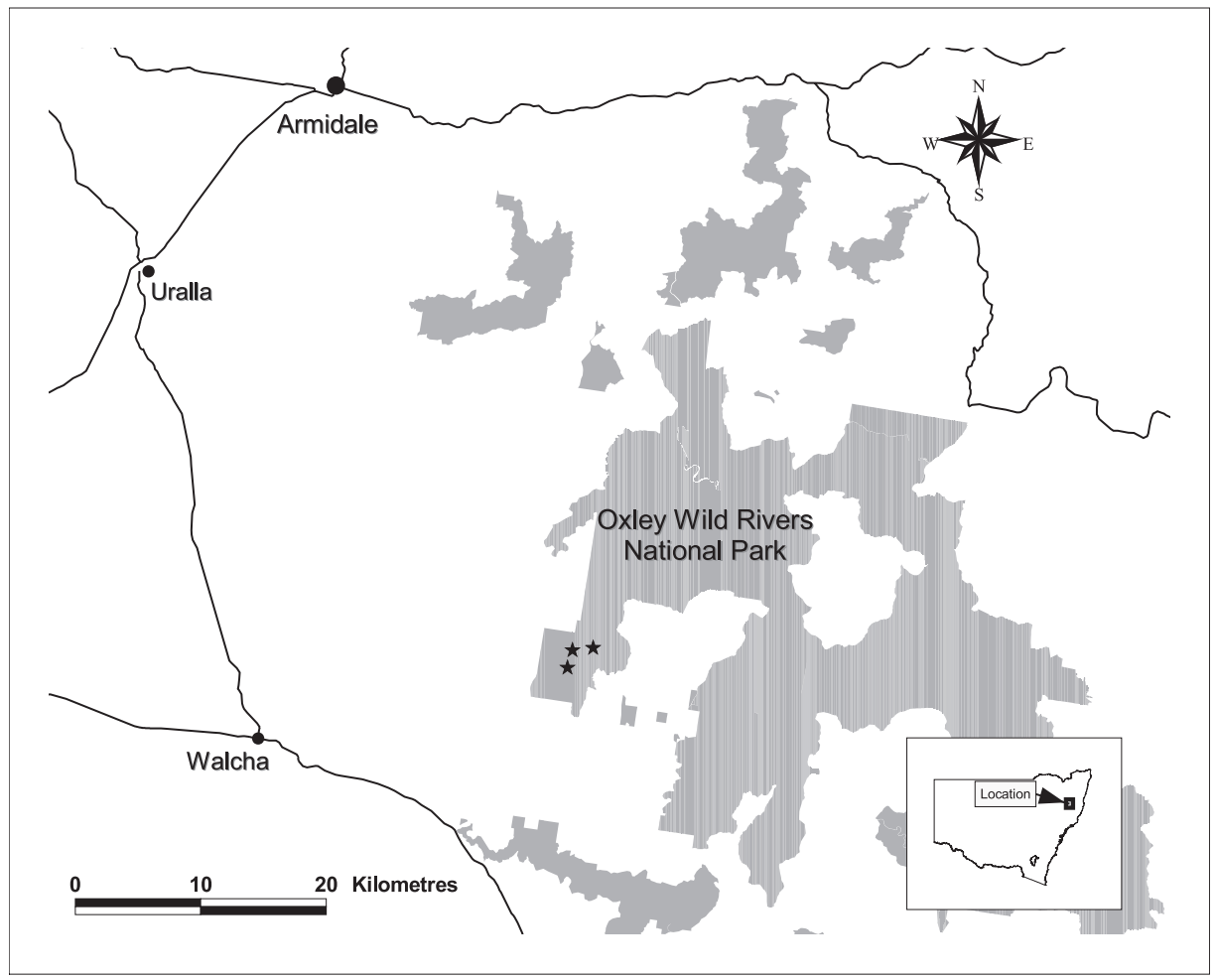

Fig. 2. The distribution of Pimelea cremnophila (denoted by $\star$ ) in northern New South Wales.

the period 2002-2003, presumably due to the extreme drought conditions endured at the time. Although all known plants are reserved in Oxley Wild Rivers National Park, the species should still be considered endangered due to its highly restricted distribution, small population size and the potential threats. A ROTAP code of 2ECit is recommended following the criteria of Briggs \& Leigh (1996).

Etymology: the specific epithet cremnophila is derived from the Greek cremnos (cliff) and philos (loving), in reference to its habitat.

Comparison with similar species: Pimelea cremnophila belongs to section Epallage (Endl.) Benth. and appears to be most similar to P. umbratica. It differs from P. umbratica by its longer, denser indumentum, less prominent secondary leaf venation, predominantly axillary inflorescences, and smaller anthers on distinct filaments (Table 1).

Sexuality in sect. Epallage requires further study. Threlfall (1983) stated that in P. umbratica, male, female and bisexual flowers may occur on the same individual. However, Threlfall included P. leptospermoides under P. umbratica and did not cite which specimens had been studied for that observation. Rye (1990) claimed P. umbratica has bisexual and female flowers. We have observed apparently functionally male (with pistillodes) and functionally female (with staminodes) flowers on the same plant. In P. cremnophila, plants appear to be polygamous, with functionally male and bisexual flowers on the same plants and only functionally female on others.

Note that in Harden (1990) the description of P. umbratica follows Threlfall (1983) with $P$. leptospermoides (a central Queensland serpentinite endemic) included in the circumscription. The leaves of $P$. leptospermoides are alternate while those of P. umbratica are in fact opposite. 
Table 1. A comparison of the distinguishing features between Pimelea cremnophila and $P$. umbratica.

Character
Secondary venation
Secondary venation angle
Inflorescence
Bisexual flower hypanthium length
Bisexual flower sepal length
Stamens
Anther length
Seed colour

\section{P. cremnophila}

obscure

$25-35^{\circ}$

mostly axillary

$4-6.5 \mathrm{~mm}$

3-4 mm

filaments present

$1.7 \mathrm{~mm}$

red-brown

\author{
P. umbratica \\ prominent \\ $40-50^{\circ}$ \\ mostly terminal \\ 5-7.5 mm \\ 2-2.5 mm \\ anthers subsessile \\ 2-2.5 mm \\ black
}

\section{Acknowledgments}

We are grateful to Sam Doak and Patrick Lupica, rangers from the NSW National Parks and Wildlife Service, for their assistance in the field. Patrick Lupica is also thanked for producing the distribution map. Jeremy Bruhl also assisted in the field and gave constructive comments on the manuscript. We would like to thank Peter Wilson for assisting with the Latin diagnosis. Directors of CANB, NSW and NE are also thanked for allowing access to specimens held within their herbaria.

\section{References}

Briggs JD \& Leigh JH (1996) Rare or Threatened Australian Plants, revised edition. (CSIRO Publishing: Collingwood)

Copeland LM (1997) Rare or Threatened Plants (ROTAPs) occurring in Oxley Wild Rivers National Park. Unpublished report produced for the NSW National Parks and Wildlife Service.

Harden GJ (1990) Thymelaeaceae. Pp. 375-387 in Harden GJ (ed.) Flora of New South Wales, vol. 1. (New South Wales University Press: Kensington)

Holmgren PK, Holmgren NH \& Barnett LC (1990) Index Herbariorum 8th Edition. (New York Botanical Garden: New York)

Rye BL (1990) Thymelaeaceae. Pp. 122-215 in George AS (ed.) Flora of Australia, vol. 18. (Australian Government Publishing Service: Canberra)

Threlfall S (1983) The genus Pimelea (Thymelaeaceae) in eastern mainland Australia. Brunonia 5: 113-201. 